\title{
Uji daya hambat ekstrak buah pala (myristica fragrans Houtt) terhadap bakteri penyebab periodontitis porphyromonas gingivalis secara in vitro
}

\author{
${ }^{1}$ Pricillia T. Kaawoan \\ ${ }^{2}$ Jemmy Abidjulu \\ ${ }^{2}$ Krista V. Siagian
}

\author{
${ }^{1}$ Kandidat Skripsi Program Studi Pendidikan Dokter Gigi Fakultas Kedeokteran \\ ${ }^{2}$ Program Studi Pendidikan Dokter Gigi Fakultas Kedeokteran \\ Email: pricillia_kaawoan@yahoo.com
}

\begin{abstract}
Periodontal disease is preceded by a buildup of plaque that contains a collection of bacteria. The most common bacteria found in plaques are Porphyromonas gingivalis that cause periodontitis. There are several ways to treat periodontitis inter alia the usage of natural materials. Nutmeg (Myristica fragrans Houtt) contains volatile oil, saponins, and alkaloids known as antibacterials. This study aimed to investigate the inhibitory effect of nutmeg extract on Porphyromonas gingivalis. This was an experimental laboratory study in vitro with a post test only control group design. The testing method used in this study was a modified method of Kirby-bauer. Nutmeg was extracted by using maceration method with ethanol 96\%. Porphyromonas gingivalis bacteria were ordered from University of Hasanuddin Makassar and then were rejuvenated in the Laboratory of Microbiology Pharmacy FMIPA University of Sam Ratulangi Manado. The results showed that the average inhibitory zone of nutmeg extract was $13,5 \mathrm{~mm}$. Conclusion: Nutmeg (Myristica fragrans Houtt) extract had an inhibitory effect on the Porphyromonas gingivalis bacteria.
\end{abstract}

Keywords: nutmeg (Myristica fragrans Houtt), inhibition zone, periodontitis, Porphyromonas gingivalis

\begin{abstract}
Abstrak: Penyakit periodontal berawal dari penumpukan plak yang mengandung kumpulan bakteri. Bakteri yang paling banyak ditemukan yaitu bakteri Porphyromonas gingivalis yang menyebabkan penyakit periodontitis. Terdapat beberapa cara untuk mengobati periodontitis, salah satunya dengan penggunaan bahan alami. Pala (Myristica fragrans Houtt) memiliki kandungan minyak atsiri, saponin, dan alkaloida yang diketahui berefek antibakteri. Penelitian ini bertujuan untuk mengetahui adanya daya hambat ekstrak buah pala terhadap bakteri penyebab periodontitis Porphyromonas gingivalis. Jenis penelitian ini ialah eksperimental laboratorik secara in vitro dengan post test only control group design. Metode pengujian yang digunakan yaitu modifikasi Kirby-bauer menggunakan sumuran. Sampel buah pala diekstraksi dengan metode maserasi menggunakan pelarut etanol $96 \%$. Bakteri Porphyromonas gingivalis yang digunakan dalam penelitian ini dikirim dari Universitas Hasanuddin Makassar yang telah diremajakan di Laboratorium Mikrobiologi Farmasi FMIPA Universitas Sam Ratulangi Manado. Hasil penelitian mendapatkan zona hambat ekstrak buah pala sebesar 13,5 mm. Simpulan: Ekstrak buah pala (Myristica fragrans Houtt) mempunyai daya hambat terhadap bakteri penyebab periodontitis Porphyromonas gingivalis.
\end{abstract}

Kata kunci: pala (Myristica fragrans Houtt), zona hambat, periodontitis, porphyromonas gingivalis 
Berdasarkan laporan Riset Kesehatan Dasar (Riskesdas) di Indonesia 2013 masalah kesehatan gigi dan mulut masih tergolong tinggi. ${ }^{1}$ Penyakit gigi dan mulut terutama penyakit periodontal berawal dari penumpukan plak dan bakteri yang paling banyak ditemukan ialah Porphyromonas gingivalis. $^{2}$

Periodontitis yaitu infeksi gusi yang dapat menyebabkan kerusakan pada jaringan lunak dan tulang penyangga. ${ }^{3}$ Periodontitis akan mengakibatkan adanya gigi goyang, pergeseran gigi hingga tanggalnya gigi-geligi. ${ }^{2}$ Banyak cara yang dilakukan untuk mengobati penyakit periodontitis Salah satunya dengan tanaman alami yaitu pala (Myristica fragrans Houtt). ${ }^{4}$ Pala mempunyai prospek yang baik karena selalu dibutuhkan, baik dalam industri makanan, minuman, obatobatan dan lain-lain. Keperluannya yang lebih spesifik yaitu pala dapat dibuat sebagai bahan antibakteri. ${ }^{5}$

Minyak atsiri dan saponin merupakan zat yang terkandung sebagai antibakteri pada pala. $^{6}$ Hasil fitokimia juga menyebutkan pala memiliki zat alkaloida sebagai antibakteri. ${ }^{7}$ Berdasarkan hal di atas maka peneliti tertarik untuk melakukan penelitian tentang uji daya hambat ekstrak buah pala terhadap bakteri penyebab periodontitis Porphyromonas gingivalis.

\section{BAHAN DAN METODE PENELITIAN}

Jenis penelitian ini ialah eksperimental laboratorik (true experimental) secara in vitro dengan post test only control group design. Penelitian ini dilaksanakan di Laboratorium Mikrobiologi Farmasi FMIPA Universitas Sam Ratulangi pada bulan April 2016.

Ekstrak buah pala (Myristica fragrans Houtt) dilakukan maserasi dengan etanol $96 \%$. Metode pengujian yang digunakan ialah metode modifikasi Kirby-Bauer dengan sumuran. Media MHA disediakan sebanyak 5 cawan petri dengan 15 buah sumur. Lima sumur pertama yang sudah terbentuk pada media agar di 5 cawan petri diisi dengan larutan ekstrak buah pala (Myristica fragrans Hout). Lima sumur berikutnya diisi obat metronidazol dengan pelarut akuades sebagai kelompok kontrol positif dan 5 sumur lainnya diisi dengan akuades sebagai kelompok kontrol negatif.

Media Brain Heart Infusion Broth (BHI-B) digunakan untuk suspensi uji bakteri yang disamakan dengan standar kekeruhan McFarland. Kekeruhan ini dipakai sebagai standar suspensi bakteri uji. Kontrol positif dibuat dengan menggunakan sediaan bubuk obat metronidazole yang dicampur dengan pelarut akuades hingga homogen. Kontrol negatif yang digunakan yaitu akuades.

Pengamatan dilakukan setelah 24 jam masa inkubasi. Zona bening yang terbentuk di sekitar sumur diukur diameter vertikal dan diameter horizontal dengan satuan millimeter $(\mathrm{mm})$ dengan menggunakan mistar. Data perhitungan hasil diameter zona hambat pada setiap bahan coba diukur melalui nilai rata-rata.

\section{HASIL PENELITIAN}

Pertumbuhan bakteri terlihat disekitaran sumur yang telah ditetesi ekstrak buah pala (Myristica fragrans Houtt) dan pada sumur yang ditetesi obat metronidazole sebagai kontrol positif, sedangkan pada sumur yang ditetesi akuades sebagai kontol negatif tidak telihat pertumbuhan bakteri. Zona hambat yang terbentuk dalam penelitian ini dapat dilihat pada Gambar 1.

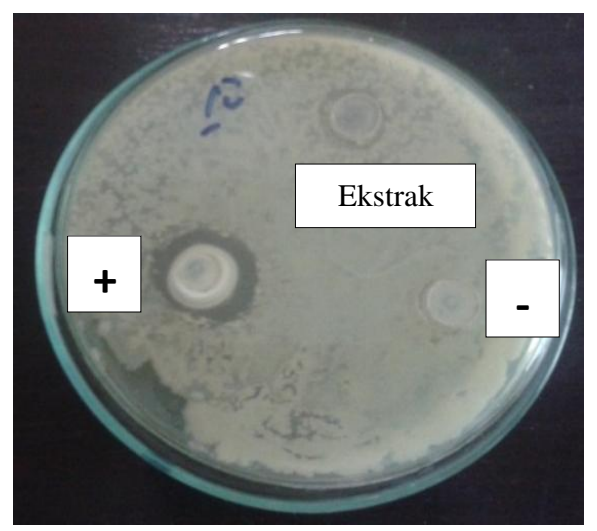

Gambar 1. Hasil diameter zona hambat

Perbandingan diameter zona hambat ekstrak buah pala, metronidazole sebagai kontrol (+), dan akuades sebagai kontrol (-) 
menggunakan rumus: $\frac{\mathrm{Dv}-\mathrm{Dh}}{2}$ kemudian dihitung reratanya.

Tabel 1 menunjukkan ekstrak buah pala memiliki daya hambat terhadap bakteri Porphyromonas gingivalis dengan rerata sebesar 13,5 mm yang termasuk kategori kuat. Obat metronidazol sebagai kelompok kontrol positif juga termasuk pada kategori kuat dengan rerata $18,9 \mathrm{~mm}$, sedangkan akuades sebagai kontrol negatif tidak memiliki daya hambat. Hal ini berdasarkan kategori respon zona hambatan menurut klasifikasi David dan Stout. Kategori respon zona hambatan digolongkan menjadi tidak ada zona hambat; lemah yaitu zona hambat kurang dari $5 \mathrm{~mm}$, sedang yaitu zona hambat 5-10 mm; kuat yaitu zona hambat $11-20 \mathrm{~mm}$; dan sangat kuat yaitu zona hambat lebih dari $20 \mathrm{~mm}{ }^{8}$

Pala memiliki kandungan saponin sebagai antibakteri dengan cara mengganggu permeabilitas membran sel bakteri. ${ }^{9,10}$ Hasil skrining fitokimia menunjukkan bahwa pala mengandung senyawa alkaloida ${ }^{7}$ yang memiliki kemampuan sebagai antibakteri. Mekanisme kerjanya dengan cara mengganggu komponen penyusun peptidoglikan pada sel bakteri, sehingga lapisan dinding sel tidak terbentuk secara utuh dan menyebabkan kematian sel tersebut. ${ }^{9,11}$ Pala juga mengandung minyak atsiri dengan komponen penyusun utama yakni monoterpen hidrokarbon, asam monoterpenes, dan aromatik eter sebagai zat anti bakteri. ${ }^{12}$ Obat metronidazole merupakan obat yang efektif melawan bakteri anaerob dan protozoa. ${ }^{13}$ Metronidazole secara selektif diserap oleh bakteri anaerob dan protozoa dan jika telah diserap oleh bakteri anaerob dan protozoa obat ini secara non-enzimetis tereduksi dengan bereaksi terhadap feredoksin tereduksi. Reduksi ini yang menghasilkan produk toksik bagi sel anaerob, metabolit dari obat metronidazole diserap ke dalam DNA bakteri dan membentuk molekul yang tak stabil. Efek ini biasanya hanya terjadi pada bakteri anaerob. ${ }^{14}$

Akuades tidak memiliki zona bening yang berarti kelompok kontrol negatif tidak memiliki daya hambat; hal ini karena akuades memiliki efektifvitas pelarut yang lebih baik. Akuades juga merupakan larutan yang netral sehingga tidak terdapat zat antibakteri. $^{15}$

Tabel 1. Perbandingan diameter zona hambat terhadap bakteri Porphyromonas gingivalis

\begin{tabular}{cccc}
\hline Cawan petri & \multicolumn{3}{c}{ Diameter zona hambat (mm) } \\
\cline { 2 - 4 } & $\begin{array}{c}\text { Ekstrak buah pala } \\
\text { (Myristica fragrans } \\
\text { Houtt) }\end{array}$ & $\begin{array}{c}\text { Obat } \\
\text { metronidazol } \\
\text { (kontrol +) }\end{array}$ & $\begin{array}{c}\text { Akuades } \\
\text { (kontrol -) }\end{array}$ \\
\hline 1 & $14,5 \mathrm{~mm}$ & $19,5 \mathrm{~mm}$ & $0 \mathrm{~mm}$ \\
2 & $13 \mathrm{~mm}$ & $17,5 \mathrm{~mm}$ & $0 \mathrm{~mm}$ \\
3 & $13 \mathrm{~mm}$ & $19,5 \mathrm{~mm}$ & $0 \mathrm{~mm}$ \\
4 & $13,5 \mathrm{~mm}$ & $20 \mathrm{~mm}$ & $0 \mathrm{~mm}$ \\
5 & $13,5 \mathrm{~mm}$ & $18 \mathrm{~mm}$ & $0 \mathrm{~mm}$ \\
Total & $67,6 \mathrm{~mm}$ & $94,5 \mathrm{~mm}$ & $0 \mathrm{~mm}$ \\
Rerata & $13,5 \mathrm{~mm}$ & $18,9 \mathrm{~mm}$ & $0 \mathrm{~mm}$ \\
Kategori & Kuat & Kuat & - \\
\hline
\end{tabular}

\section{SIMPULAN}

Ekstrak buah pala (Myristica fragrans Houtt) memiliki daya hambat terhadap bakteri Porphyromonas gingivalis dengan rerata zona hambat $13,5 \mathrm{~mm}$ yang termasuk dalam kategori kuat.

\section{SARAN}

Perlu dilakukan penelitian lebih lanjut mengenai buah pala (Myristica fragrans 
Houtt) terhadap bakteri Porphyromonas gingivalis pada berbagai kosentrasi sehingga dapat diketahui minimum inhibitor concentration (MIC).

\section{DAFTAR PUSTAKA}

1. Riset Kesehatan Dasar (RISKESDAS) Nasional 2013. Badan Pemeliharaan dan Pengembangan Kesehatan Departemen Kesehatan RI, 2013; p. 110-1.

2. Langkis RP. Lesi Mulut yang Sering Ditemukan (4th ed). Jakarta: EGC; p. 82-102.

3. Harty FJ, Ogston R. Kamus Kedokteran Gigi. Jakarta: EGC, 1995; p. 232.

4. Pratiwi EW, Praharan D, Arina YMD. Daya hambat ekstrak daun pepaya (Carica papaya. L) terhadap adeshi bakteri Porphyromonas gingivalis pada neutrofil. Pustaka Jurnal. 2015;3(2):193.

5. Putra WS. Kitab Herbal Nusantara. Jakarta: Katahati, 2015; p. 295-99.

6. Nurd JN, Mulyono E, Risfaher. Teknologi Pengelolaan Pala. Badan Penelitian Pertanian, 2007; p. 4-12.

7. Palawi JF. Isolasi senyawa alkoloida dari biji buah pala (Myristica fragrans Houtt). [Skripsi]. Medan: Universitas Sumatra Utara; 2014.

8. Davis WW, Stout TR. Disc Plate Method of
Microbiological Antibiotic Assay. Appl Microbiol. 1971;22(4):659-65.

9. I Gede Oka D, I Nengah KB, Mahatmi H. Potensi daun binahong (Anredera cordifolia) dalam menghamabat pertumbuhan bakteri Escericihia Coli secara in vitro. Indonesia Medicus Veterinus. 2012;1(3);337-49.

10. Ganiswarna S. Farmakologi dan Terapi (4th ed). Jakarta: Penerbit UI, 1995.

11. Robinson T. Kandungan Tumbuhan Tinggi (6th ed). Padwinata $\mathrm{K}$, penerjemah. Bandung: ITB, 1995.

12. Rastuti U, Widyaningsi S, Kartika D, Ningsi D. Aktivitas antibakteri minyak atsiri daun pala dari Banyumas terhadap Streptococcus Aureus dan Escherichia coli serta identifikasi senyawa penyusunnya. Purwokerto: Universitas Jenderal Soedirman; p. 197-203.

13. Maridjono M. Farmakologi dan Terapi. Jakarta: Balai Penerbit FKUI, 2012; p. 552-3.

14. Katzung BG, Masters SB, Trevor AJ. Farmakologi Dasar dan Klinik (12th ed). Jakarta: EGC, 2012; p.1009.

15. Sukarsono K, Marhaendrajaya I, Firdausi KS. Studi efek Kerr untuk pengujian tingkat kemurnian akuades, air PAM dan air sumur. Jurnal Fisika FMIPA Undip. 2008;11(1):9. 